\title{
Functional morphology of intertidal seaweeds: adaptive significance of aggregate vs. solitary forms
}

\author{
Phillip R. Taylor ${ }^{1 *}$ and Mark E. Hay ${ }^{2}$ \\ ${ }^{1}$ Department of Ecology and Evolutionary Biology, University of California, Irvine, California 92717, USA \\ ${ }^{2}$ University of North Carolina at Chapel Hill, Institute of Marine Sciences, Morehead City, North Carolina 28557, USA
}

\begin{abstract}
Many intertidal seaweeds show a tremendous gradient of morphological form ranging from spatially separated thalli, to thalli that are aggregated into dense turfs. Aggregation of seaweeds into turfs decreases productivity per g organic weight due to crowding of thalli but increases resistance to desiccation. The intertidal distribution of the turf growth form is correlated with the intensity of desiccation stress. Also turfs transplanted into tide pools developed the non-turf morphology, while non-turfs transplanted to emergent substrate either developed the turf form or died. The turf growth form is energetically expensive; apparent productivity of turfs was 23 to $48 \%$ less than that of individuals. Increasing light and nutrients available to turfs by separating the thalli increased apparent productivity by 36 to $113 \%$. We tested the hypothesis that these turfs minimize energetic costs of this aggregated growth form through the spatial partitioning of photosynthetic and respirative activity. The lower portions of turfs showed less apparent photosynthesis than the upper portions (reductions of 37 to $85 \%$ ); however, this spatial partitioning was also found in the individual forms (37 to $63 \%$ reductions) of these relatively simple seaweeds. Spatial differentiation of respiration was similar in turfs and nonturfs. The seaweeds, examined are able to alter the extent of thalli compaction in accordance with varying levels of environmental stress. This phenotypic plasticity allows seaweeds to adopt morphological features that maximize fitness in a wide variety of habitats without being developmentally committed.
\end{abstract}

\section{INTRODUCTION}

Many seaweeds are known for remarkable variation in morphology both between and within populations. However, the etiology of this plasticity in natural populations and the benefits and costs of assuming the various forms have largely remained unexplored by field experimentation (see Steneck and Adey, 1976; Gerard and Mann, 1979; Littler and Littler, 1980; Lubchenco and Cubit, 1980; Slocum, 1980; Dethier, 1981; Hay, 1981 for some recent developments along this line).

Many intertidal seaweeds show a gradient of form from an individual upright thallus to a tightly clumped aggregate of upright and lateral branches. Since the

\footnotetext{
- Present address: Division of Science and Mathematics, College of the Virgin Islands, St. Thomas, US Virgin Islands 00802
}

latter forms often cover substrate in large continuous mats, we call these 'turfs'. The inherent costs of the turf configuration have been investigated in temperate freshwater streams (Pfeifer and McDiffett, 1975) and on tropical reefs (Hay, 1981). Results have shown photosynthetic performances to be inversely related to the degree of compaction, probably due to self-shading and nutrient limitation within the turf matrix. Hay (1981) has shown that the turf morphology decreases the damage suffered due to desiccation or herbivory; however, field experiments showing that environmental stress or biological disturbance can directly cause turf development have not been carried out.

In this study, we transplanted common turf-forming seaweeds between microhabitats to investigate how environmental variability affects seaweed growth form. We also assessed the generality of many of the physiological responses documented by Hay (1981) for Caribbean seaweeds by repeating several physiologi- 
cal studies using temperate seaweeds from the Northeastern Pacific Ocean.

We tested the following hypotheses: (1) the compact configuration of turfs should result in reduced photosynthetic performance; (2) to curtail maintenance expenses, the concentration of photosynthetic apparatus in the lower portions of thalli should be reduced, resulting in diminished dark respiration and apparent photosynthetic rates; (3) differences between photosynthetic and dark respiration rates in upper and lower portions of the thallus should be much greater for turf forms than for non-turf forms of the same species; (4) because the turf form shields basal attachment regions, it should reduce the probability of herbivores biting through the base and causing total loss of the algal thallus; thus, turf formation should reduce biomass loss due to herbivory; (5) dense packing of thalli in the turf growth form should enhance desiccation resistance and reduce the loss of biomass associated with desiccating environmental conditions; (6) when turfs are protected from desiccation and herbivory, they should abandon the energetically expensive turf form and grow like the less densely compacted non-turfs.

\section{STUDY SITE AND ORGANISMS}

The study was conducted on the northwest end of San Nicolas Island, California. The US Navy restricts access to the island and the littoral communities are some of the most pristine in California. Our study site was a large sandstone point with abundant tide pools, deeply cut tidal channels, and bedrock protuberances. The site harbors abundant intertidal grazers including sea urchins, black abalone, crabs, limpets, chitons and tide-pool fish. During low tides, urchins are confined to pools and channels and show little movement from these areas. Other groups of grazers are widely distributed.

The 4 seaweed species used in various aspects of this investigation are common in Californian rocky littoral systems (Abbott and Hollenberg, 1976); they show considerable phenotypic variation on San Nicolas Island and throughout southern California. All 4 species exist as loose clumps or individual thalli and as densely compacted clumps referred to here as turfs. Corallina vancouveriensis Yendo and Lithothrix aspergillum Gray are articulate coralline algae. Both grow to about $8 \mathrm{~cm}$ tall in the non-turf form, usually less than $4 \mathrm{~cm}$ tall in the compacted turf. Gelidium coulteri Harvey and Rhodoglossum affine (Harvey) Kylin are fleshy red algae, growing to 10 and $15 \mathrm{~cm}$ tall, respectively. Both show considerable variation in branching, size and the degree of clumping.

\section{MATERIALS AND METHODS}

A number of different measurements were made to quantify morphological attributes of the turf and nonturf forms of the species studied. These were: (1) dry mass per volume of space occupied and per area of substrate occupied; (2) ash-free dry mass per volume and per area; and (3) thallus area per volume and per area. Plants were collected for these measurements by driving a $2.1 \mathrm{~cm}$ diameter metal pipe through the plants and into the substrate. For the turf form of Corallina vancouveriensis, which has a well developed crustose system, the area of occupied substrate was equal to the area of substratum cut by the corer $\left(3.5 \mathrm{~cm}^{2}\right)$. The attachment area of non-turf specimens of C. vancouveriensis was estimated by measuring the widest diameter of the basal crust of 5 specimens and assuming that these crust were circular. Gelidium coulteri turfs do not have a crustose system but have multiple attachment points from a system of prostrate branches. The average number of attachments and the average area of single attachments were measured for small subsections ( $<1 \mathrm{~cm}$ diameter) of cored turfs with a dissecting microscope. The attachment area for nonturf $G$. coulteri was estimated using the widest diameter of 20 attachments.

The volume of occupied space was determined using the radius of the coring tube and the mean height of eight intact thalli (fewer in the case of non-turf individuals). Thallus area was quantified with a LICOR Instruments (LI 3100) area meter that measures the areas of 2-dimensional projections. We assumed that thalli were basically cylindrical and multiplied these values by pi to estimate thallus surface area.

Photosynthesis was measured in the field on San Nicolas Island during August 1980 at a water temperature of $18^{\circ} \mathrm{C}$. Incubations of each species were carried out simultaneously between 1000 and $1400 \mathrm{~h}$ (light bottles) and 1200 and $1600 \mathrm{~h}$ (dark bottles). Light levels, measured with a LICOR 185 quantum/photometer, ranged from 1200 to $1850 \mu \mathrm{E} \mathrm{m}^{-2} \mathrm{~s}^{-1}$. Determinations of apparent photosynthesis and respiration were made with a YSI 57 oxygen meter using $1114 \mathrm{ml}$ widemouth, clamp-lid bottles as incubation chambers (light, dark and blank). Seawater was agitated vigorously before incubation to achieve oxygen saturation. Six light and 6 dark replicates were used for each treatment. To create dark chambers, bottles were wrapped in heavy-duty aluminum foil. All chambers were agitated at 10 to $15 \mathrm{~min}$ intervals during incubation using magnetic stirrers and manual shaking. Elaboration on the general methodology can be found in Littler and Arnold (1980).

Turf and non-turf specimens of Corallina vancouveriensis, Gelidium coulteri and Rhodoglossum 
affine were collected while submerged and kept in fresh, ambient seawater prior to incubation. To test the hypothesis that compaction of thalli within the turf form results in decreased photosynthesis, representative specimens of the following morphological categories were incubated for each species: (1) the tightly clumped turf form, (2) 'individuals' made by pulling apart turfs, and (3) the natural non-turf form. For each species, approximately equal weights of algae were used in all treatments. In $C$. vancouveriensis, the non-turf form exists as loose clumps (several upright thalli from a small crustose base) that exhibit considerable overlap and self-shading. These were incubated as separated thalli as well.

Spatial separation of photosynthetic and respiration activity within the thallus was assessed by incubating the upper and lower thirds of turf and non-turf thalli.

To evaluate the effects of desiccation on algal morphology, turf and non-turf forms were reciprocally transplanted between tide pools and emergent substratum. Algae were transplanted with attached substratum (sandstone) and fastened to the bedrock with squares of stainless steel cloth $(10 \times 10 \mathrm{~cm}, 16$ gauge, $1.3 \mathrm{~cm}$ mesh), marine epoxy and a lag-bolt/plastic anchor system. Since herbivores are common in tide pools at this site, the effect of grazers on algal morphology was assessed by placing stainless steel cages $(15 \times 15 \times 10 \mathrm{~cm}$ high $)$ over some groups of transplants. Four cages served as herbivore exclosures and 4 roofs ( $10 \mathrm{~cm}$ above the substrate) acted as cage controls. Four transplants without roofs or cages were also placed in the pools. Morphological characteristics of turf and non-turf forms were determined from core samples taken at the time transplants were performed. Alterations in morphology were assessed by coring the transplants after $120 \mathrm{~d}$.

Changes in \% cover and viability of turf and non-turf forms in the different treatments were assessed photographimetrically as described in Taylor and Littler (1982). Algal bleaching and change in size were quantified using a point-intercept method on projected transparencies (dot density $=4 \mathrm{~cm}^{-2}, 2$ repetitive scorings; see Bonner, 1975, for a discussion of area estimates from dots).

Intertidal distribution and relative abundances of turf and non-turf forms of Corallina vancouveriensis, Gelidium coulteri and Lithothrix aspergillum were quantified with a series of line transects placed at 3 different tidal levels (low: -0.5 to $+1.0 \mathrm{~m}$ above MLLW; mid: +1.5 to $2.0 \mathrm{~m}$; high: +2.5 to $3.0 \mathrm{~m}$ ). Each turf or non-turf sclump (individuals in the case of $G$. coulteri) within $10 \mathrm{~cm}$ on either side of a transect tape was scored on two criteria: (1) morphology (turf, nonturf or intermediate in form), and (2) microhabitat (within a pool, on the edge of a pool or on fully emergent substratum). This census was performed when all pools were maximally drained. We employed the contingency table analysis on frequency data to test the null hypothesis of independence between microhabitat and morphology. The Mann-Whitney UTest and T-test were employed for analyses of 2-sample comparisons. Single Factor Analysis of Variance and the Student-Newman-Keuls Test were used for multiple comparisons.

\section{RESULTS}

Morphological differences in the tightly clumped turf and the open, non-turf forms of Corallina vancouveriensis and Gelidium coulteri are shown in Table 1. In both species' the turf form had significantly greater $(\mathrm{P}<.001$, Student's $t$-test) amounts of dry thallus mass, organic tissue, and thallus area per volume than the non-turf form (approximately 2- and 3-fold differences in $C$. vancouveriensis and G. coulteri, respectively) indicating an increased packing of biomass to create the turf morphology.

Per unit of occupied substratum, dry mass, organic mass and thallus area were greater in the non-turf forms of both Corallina vancouveriensis $(\mathrm{P}<.001)$ and Gelidium coulteri $(\mathrm{P}<.001)$, suggesting more efficient use of primary substratum by the non-turf forms. The non-turf form of $G$. coulteri had significantly $(\mathrm{P}<.05)$ more organic content than did the turf form; this pattern did not hold for C. vancouveriensis (Table 1).

The microhabitat distributions of turf, non-turf and intermediate morphologies are shown in Table 2 for Corallina vancouveriensis, Lithothrix aspergillum and Gelidium coulteri. Contingency table analysis revealed a highly significant $(\mathrm{P} \ll .001)$ interdependence between microhabitat and morphological variables, suggesting a relation between thermal/desiccation effects and the observed distribution. In all 3 species, the non-turf form was found predominantly in tide pool microhabitats, turfs were strongly associated with emergent substratum and the intermediate forms were most abundant around the edge of tide pools or in water seepage areas.

All 3 species showed significantly lower net photosynthetic capacities in turf relative to non-turf forms (Table 3; P <.05). Turf levels of photosynthesis were 57, 52 and $77 \%$ of the non-turf values in Corallina vancouveriensis, Gelidium coulteri and Rhodoglossum affine, respectively. A repeat of the experiment with $C$. vancouveriensis in January 1980 at Corona del Mar, California yielded similar results. Net photosynthesis of intact turfs $\left(1.73 \pm .51 \mathrm{mg} \mathrm{C} \mathrm{g}^{-1} \mathrm{~h}^{-1}\right)$ was only $48 \%$ of that in intact non-turfs $\left(3.62 \pm 1.13 \mathrm{mg} \mathrm{C} \mathrm{g}^{-1} \mathrm{~h}^{-1}\right)$.

Increasing the light and nutrient concentrations available to turfs by breaking the matrix apart yielded 
Table 1. Corallina vancouveriensis and Gelidium coulteri. Morphological characteristics of turf and non-turf forms. See methods on volume, substrate area and thallus area measures. $\%$ organic is ash-free dry mass/dry mass $\times 100$. Variation shown as \pm 1 standard error. P-values are results of the Student's $t$-test

\begin{tabular}{|c|c|c|c|c|}
\hline Species & Morphological character & Turf & Non-turf & P-value \\
\hline \multirow[t]{7}{*}{ Corallina vancouveriensis } & Dry mass/volume $\left(\mathrm{g} \mathrm{cm}^{-3}\right)$ & $.27 \pm .02$ & $.13 \pm .01$ & $<.001$ \\
\hline & Ash-free mass/volume $\left(\mathrm{g} \mathrm{cm}^{-3}\right)$ & $.046 \pm .003$ & $.023 \pm .003$ & $<.001$ \\
\hline & Thallus area/volume $\left(\mathrm{cm}^{2} \mathrm{~cm}^{-3}\right)$ & $27.3 \pm 1.9$ & $12.2 \pm 1.8$ & $<.001$ \\
\hline & $\begin{array}{l}\text { Dry mass/area of occupied } \\
1^{\circ} \text { substratum }\left(\mathrm{g} \mathrm{cm}^{-2}\right)\end{array}$ & $.46 \pm .03$ & $9.15 \pm 0.5$ & $<.001$ \\
\hline & $\begin{array}{l}\text { Ash-free mass/area of occupied } \\
1^{\circ} \text { substratum }\left(\mathrm{g} \mathrm{cm}^{-2}\right)\end{array}$ & $.08 \pm .004$ & $1.65 \pm .17$ & $<.001$ \\
\hline & $\begin{array}{l}\text { Thallus area/area of occupied } \\
1^{\circ} \text { substratum }\left(\mathrm{cm}^{2} \mathrm{~cm}^{-2}\right)\end{array}$ & $48.7 \pm 1.0$ & $571.8 \pm 109.7$ & $<.001$ \\
\hline & $\begin{array}{l}\% \text { organic } \\
\mathrm{N}\end{array}$ & $16.7 \pm .62$ & $\frac{18.1 \pm .94}{6}$ & $>0.10$ \\
\hline \multirow[t]{7}{*}{ Gelidium coulteri } & Dry mass/volume & $.091 \pm .010$ & $.030 \pm .007$ & $<.001$ \\
\hline & Ash-free mass/volume & $.064 \pm .007$ & $.023 \pm .005$ & $<.001$ \\
\hline & Thallus area/volume & $27.3 \pm 3.1$ & $6.3 \pm 1.2$ & $<.001$ \\
\hline & $\begin{array}{l}\text { Dry mass/area of occupied } \\
1^{\circ} \text { substratum }\end{array}$ & $1.03 \pm .15$ & $50.7 \pm 9.6$ & $<.001$ \\
\hline & $\begin{array}{l}\text { Ash-free mass/area of occupied } \\
1^{\circ} \text { substratum }\end{array}$ & $.73 \pm .09$ & $39.1 \pm 6.6$ & $<.001$ \\
\hline & $\begin{array}{l}\text { Thallus area/area of occupied } \\
1^{\circ} \text { substratum }\end{array}$ & $260.8 \pm 10.9$ & $427.9 \pm 59.6$ & $<.001$ \\
\hline & $\begin{array}{l}\% \text { organic } \\
\mathrm{N}\end{array}$ & $70.9 \pm 2.2$ & $\begin{array}{c}78.6 \pm 1.7 \\
6\end{array}$ & $<0.5$ \\
\hline
\end{tabular}

Table 2. Corallina vancouveriensis, Lithothrix aspergillum, Gelidium coulteri. Relative abundance (\%) of morphological types (turf, non-turf or individuals, and intermediate forms' located in tidepools, on pool edges and on emergent substratum. P-values are results of Contingency Table Analysis

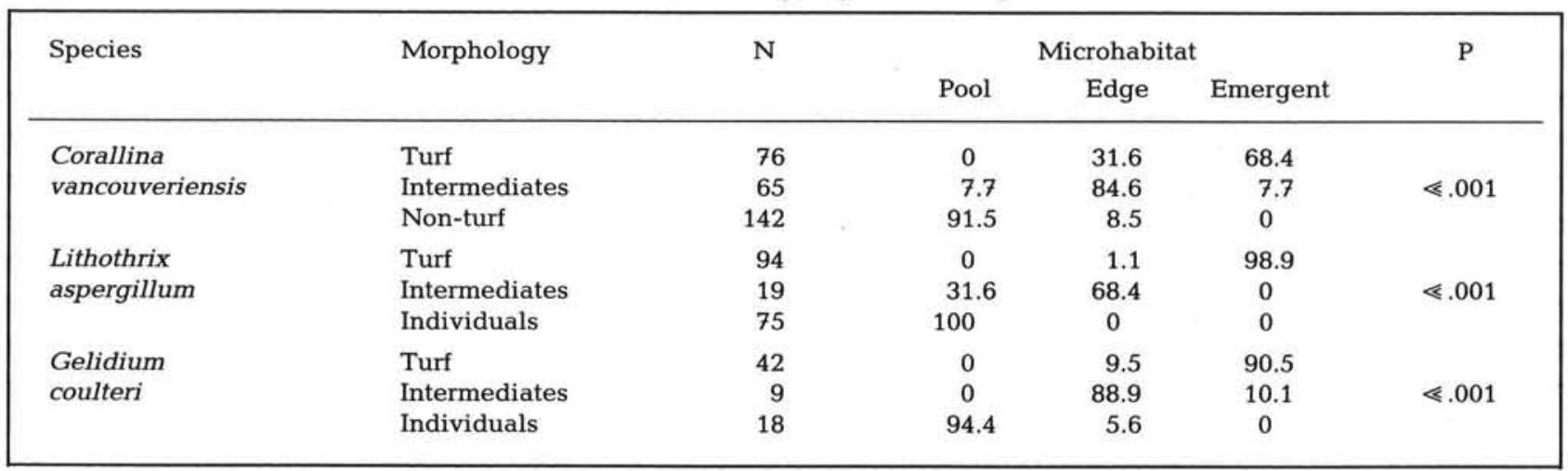

significant increases (Table 3 ) in net photosynthesis in Gelidium coulteri $(+113 \%, \mathrm{P}<.001)$ and Rhodoglossum affine $(+39 \% \mathrm{P}<.05)$. Corallina vancouveriensis showed a non-significant increase (+36 \% P > .05).

The non-turf form of Corallina vancouveriensis showed a $43 \%$ increase (Table $3, \mathrm{P}<.001$ ) when the thalli were separated, suggesting that shading or diffusion barriers can be important in photosynthetic performances even in loosely arranged algae.

Comparisons of productivity in separated turfs and the separated non-turfs of Corallina vancouveriensis (Table 3 ) revealed that the turf forms have significantly lower photosynthetic potential than non-turf forms
$(\mathrm{P}<.001)$ even when light and nutrient availability are increased by separating the turf. In Gelidium coulteri and Rhodoglossum affine, individuals and separated turfs do not exhibit significant differences in photosynthetic potential (Table $3, P \gg .10$ ). When separated, the turf forms of these species are capable of efficiently utilizing the increased light and nutrient levels.

Greater rates of net photosynthesis $(\mathrm{P}<.005)$ were found in the upper portions of all algal/morphological categories, relative to lower portions (Table 4). In the non-turf forms of Corallina vancouveriensis and Gelidium coulteri, the lower portions of thalli showed 
Table 3. Corallina vancouveriensis, Gelidium coulteri, Rhodoglossum affine. Net photosynthesis and dark respiration rates of turf and non-turf forms. Rates expressed in $\mathrm{mg} \mathrm{C} \mathrm{g}^{-1}$ organic weight $\mathrm{h}^{-1} \pm 1$ standard error. $\mathrm{N}$ equals 6 for each determination. $\mathrm{P}$ values are results of Student-Newman-Keuls Test

\begin{tabular}{|c|c|c|c|c|c|c|c|c|}
\hline Species & Form & Treatment & $\begin{array}{c}\text { Net } \\
\text { photosyn. }\end{array}$ & $\begin{array}{l}\text { Treatment } \\
\text { comparisons }\end{array}$ & P-value & $\begin{array}{l}\text { Dark } \\
\text { respiration }\end{array}$ & $\begin{array}{l}\text { Treatment } \\
\text { comparisons }\end{array}$ & P-value \\
\hline \multirow[t]{2}{*}{$\begin{array}{l}\text { Corallina } \\
\text { vancouveriensis }\end{array}$} & Turf & $\begin{array}{l}\text { Intact (1) } \\
\text { Separated (2) }\end{array}$ & $\begin{array}{r}.84 \pm .08 \\
1.14 \pm .13\end{array}$ & $\begin{array}{l}\text { (1) vs. (3) } \\
\text { (1) vs. (2) }\end{array}$ & $\begin{array}{l}<.005 \\
>.05\end{array}$ & $\begin{array}{l}-.24 \pm .02 \\
-.42 \pm .05\end{array}$ & $\begin{array}{l}\text { (1) vs. (3) } \\
\text { (1) vs. (2) }\end{array}$ & $\begin{array}{l}>.10 \\
<.05\end{array}$ \\
\hline & Non-turf & $\begin{array}{l}\text { Intact (3) } \\
\text { Separated (4) }\end{array}$ & $\begin{array}{l}1.48 \pm .11 \\
2.12 \pm .09\end{array}$ & $\begin{array}{l}\text { (2) vs. (4) } \\
\text { (3) vs. (4) }\end{array}$ & $\begin{array}{l}<.001 \\
<.001\end{array}$ & $\begin{array}{l}-.28+.03 \\
-.27 \pm .02\end{array}$ & $\begin{array}{l}\text { (2) vs. (4) } \\
\text { (3) vs. (4) }\end{array}$ & $\begin{array}{l}<.05 \\
>.10\end{array}$ \\
\hline \multirow[t]{2}{*}{$\begin{array}{l}\text { Gelidium } \\
\text { coulteri }\end{array}$} & Turf & $\begin{array}{l}\text { Intact (5) } \\
\text { Separated (6) }\end{array}$ & $\begin{array}{r}.75 \pm .07 \\
1.60 \pm .08\end{array}$ & $\begin{array}{l}\text { (5) vs. (7) } \\
\text { (5) vs. (6) }\end{array}$ & $\begin{array}{l}<.001 \\
<.001\end{array}$ & $\begin{array}{l}-.13 \pm .01 \\
-.26 \pm .02\end{array}$ & $\begin{array}{l}\text { (5) vs. (7) } \\
\text { (5) vs. (6) }\end{array}$ & $\begin{array}{l}<.001 \\
<.001\end{array}$ \\
\hline & Individuals & (7) & $1.45 \pm .13$ & (6) vs. (7) & $>.10$ & $-.30 \pm .02$ & (6) vs. (7) & $>.10$ \\
\hline \multirow[t]{2}{*}{$\begin{array}{l}\text { Rhodoglossum } \\
\text { affine }\end{array}$} & Turf & $\begin{array}{l}\text { Intact (8) } \\
\text { Separated (9) }\end{array}$ & $\begin{array}{r}.72 \pm .04 \\
1.00 \pm .10\end{array}$ & $\begin{array}{l}\text { (8) vs. (10) } \\
\text { (8) vs. (9) }\end{array}$ & $\begin{array}{l}<.05 \\
<.05\end{array}$ & $\begin{array}{l}-.18 \pm .02 \\
-.19 \pm .01\end{array}$ & $\begin{array}{l}\text { (8) vs. (10) } \\
\text { (8) vs. (9) }\end{array}$ & $\begin{array}{l}>.10 \\
>.10\end{array}$ \\
\hline & Individuals & (10) & $.94 \pm .04$ & (9) vs. (10) & $>.10$ & $-.18 \pm .02$ & (9) vs. (10) & $>.10$ \\
\hline
\end{tabular}

Table 4. Corallina vancouveriensis, Gelidium coulteri, Rhodoglossum affine. Net photosynthesis and dark respiration rates of upper and basal portions of both turf and non-turf forms. Rates expressed in $\mathrm{mg} \mathrm{C} \mathrm{g}^{-1}$ organic wt $\mathrm{h}^{-1} \pm 1$ standard error. P-values are results of Student's $t$-test. $N$ equals 6 for each determination

\begin{tabular}{|c|c|c|c|c|c|c|c|c|}
\hline Species & Form & Treatment & $\begin{array}{c}\text { Net } \\
\text { photosyn. }\end{array}$ & $P$ & $\% \Delta$ & $\begin{array}{l}\text { Dark } \\
\text { resp. }\end{array}$ & $\mathrm{P}$ & $\% \Delta$ \\
\hline \multirow[t]{2}{*}{$\begin{array}{l}\text { Corallina } \\
\text { vancouveriensis }\end{array}$} & Turf & $\begin{array}{l}\text { Tops } \\
\text { Bottoms }\end{array}$ & $\begin{array}{r}1.64 \pm .19 \\
.25 \pm .03\end{array}$ & $<.001$ & $-85 \%$ & $\begin{array}{l}-.57 \pm .08 \\
-.32 \pm .05\end{array}$ & $<.025$ & $-44 \%$ \\
\hline & Non-turf & $\begin{array}{l}\text { Tops } \\
\text { Bottoms }\end{array}$ & $\begin{array}{r}1.87 \pm .12 \\
.87 \pm .13\end{array}$ & $<.001$ & $-53 \%$ & $\begin{array}{l}-.53 \pm .02 \\
-.29 \pm .03\end{array}$ & $<.001$ & $-45 \%$ \\
\hline \multirow[t]{2}{*}{$\begin{array}{l}\text { Gelidium } \\
\text { coulteri }\end{array}$} & Turf & $\begin{array}{l}\text { Tops } \\
\text { Bottoms }\end{array}$ & $\begin{array}{l}1.84 \pm .08 \\
1.16 \pm .02\end{array}$ & $<.001$ & $-37 \%$ & $\begin{array}{l}-.26 \pm .03 \\
-.30 \pm .05\end{array}$ & $>.20$ & $+15 \%$ \\
\hline & Non-turf & $\begin{array}{l}\text { Tops } \\
\text { Bottoms }\end{array}$ & $\begin{array}{l}2.60 \pm .17 \\
1.64 \pm .06\end{array}$ & $<.005$ & $-37 \%$ & $\begin{array}{l}-.40 \pm .04 \\
-.27 \pm .04\end{array}$ & $<.05$ & $-32 \%$ \\
\hline \multirow[t]{2}{*}{$\begin{array}{l}\text { Rhodoglossum } \\
\text { affine }\end{array}$} & Turf & $\begin{array}{l}\text { Tops } \\
\text { Bottoms }\end{array}$ & $\begin{array}{r}1.32 \pm .06 \\
.81 \pm .04\end{array}$ & $<.001$ & $-35 \%$ & $\begin{array}{l}-.24 \pm .03 \\
-.19 \pm .03\end{array}$ & $>.10$ & $-21 \%$ \\
\hline & Non-turf & $\begin{array}{l}\text { Tops } \\
\text { Bottoms }\end{array}$ & $\begin{array}{r}1.32 \pm .06 \\
.49 \pm .06\end{array}$ & $<.001$ & $-63 \%$ & $\begin{array}{l}-.24 \pm .03 \\
-.15 \pm .05\end{array}$ & $>.10$ & $-38 \%$ \\
\hline
\end{tabular}

significantly reduced rates of dark respiration $(\mathrm{P}<.001$ and $\mathrm{P}<.05$, respectively). With the exception of Corallina vancouveriensis $(\mathrm{P}<.025)$, respiration rates in the upper and lower portions of turfs were not significantly different $(\mathrm{P}>.10)$. Though the lower portions of turfs exhibit productivity even further reduced from that observed in the non-turfs of $C$. vancouveriensis and G. coulteri $(\mathrm{P}<.005)$, comparisons of respiration rates revealed that no further reduction in maintenance costs of basal sections of upright thalli was evident $(\mathrm{P}>.10$; Table 4$)$ in any of the three algal species tested.

When transplanted to tide pools, all turf specimens of Corallina vancouveriensis and Gelidium coulteriwhether caged, covered with a roof or free from structural manipulation - developed a non-turf morphology (Table 5; compare with Table 1) and became indistin- guishable from natural non-turfs $(\mathrm{P} \gg .10)$ on the basis of dry weight and biomass per volume. This suggests that desiccation is a primary factor maintaining the turf morphology. All non-turf forms of $C$. vancouveriensis and $G$. coulteri that were transplanted to emergent substratum, bleached and died completely (Table 6) or died back to basal crusts and regenerated as turfs. Non-turf specimens of $C$. vancouveriensis transplanted to pools as manipulation controls showed no changes. In addition, $C$. vancouveriensis turfs transplanted to emergent substratum as controls maintained the turf morphology; some became more compacted (turf-like) following desiccation (Table 6). With one exception, all $G$. coulteri (both turfs and individuals) transplanted into open areas in pools were lost before the experiment's end. We assume that this loss was due to urchin grazing. The persistence of $G$. coulteri beneath roofs is 
Table 5. Corallina vancouveriensis, Gelidium coulteri. Morphological characteristics of turf forms following experimental exposure to constant submergence and tidepool grazers for $3 \mathrm{mo}$. Weights expressed in $\mathrm{g}$, volume as $\mathrm{cm}^{3}$. Variation is shown as \pm 1 standard error. Controls transplanted between submerged substrates showed no significant changes. See Table 1 for values for turfs and non-turfs. P-values are results of the Student-Newman-Keuls Test

\begin{tabular}{|c|c|c|c|c|}
\hline \multirow[t]{2}{*}{ Species } & \multirow[t]{2}{*}{ Morphological character } & \multicolumn{3}{|c|}{ Treatment } \\
\hline & & Caged & Roofed & Unobstructed \\
\hline $\begin{array}{l}\text { Corallina } \\
\text { vancouveriensis }\end{array}$ & $\begin{array}{l}\text { Dry wt/volume } \\
\text { Ash-free wt/volume } \\
\mathrm{N}\end{array}$ & $\begin{array}{c}.15 \pm .015^{\mathrm{a}} \\
.018 \pm .003^{\mathrm{b}} \\
12\end{array}$ & $\begin{array}{c}.11 \pm .009^{\mathrm{a}} \\
.017 \pm .002^{\mathrm{b}} \\
9\end{array}$ & $\begin{array}{c}.11 \pm .008^{\mathrm{a}} \\
.015 \pm .001^{\mathrm{b}} \\
10\end{array}$ \\
\hline $\begin{array}{l}\text { Gelidium } \\
\text { coulteri }\end{array}$ & $\begin{array}{l}\text { Dry wt/volume } \\
\text { Ash-free wt/volume } \\
\mathrm{N}\end{array}$ & $\begin{array}{c}.025 \pm .003^{\mathrm{a}} \\
.018 \pm .002^{\mathrm{a}} \\
13\end{array}$ & $\begin{array}{c}.034 \pm .007^{a} \\
.024 \pm .006^{a} \\
7\end{array}$ & $\begin{array}{r}.007^{\circ} \\
.005^{\circ} \\
1^{\bullet}\end{array}$ \\
\hline
\end{tabular}

Table 6. Corallina vancouveriensis, Gelidium coulteri. Impact of aerial exposure on turf and non-turf forms in terms of percentage of thalli suffering bleaching and biomass loss. Data represent mean percentages \pm 1 standard error. P-values are results of the Mann-Whitney U-Test

\begin{tabular}{|c|c|c|c|c|c|c|c|}
\hline Species & Period & Form & $\mathrm{N}$ & $\begin{array}{c}\% \\
\text { Bleached }\end{array}$ & $\mathrm{P}$ & $\begin{array}{l}\% \text { Change } \\
\text { in cover }\end{array}$ & $\mathrm{P}$ \\
\hline \multirow[t]{3}{*}{$\begin{array}{l}\text { Corallina } \\
\text { vancouveriensis }\end{array}$} & $4-26$ Oct 1980 & $\begin{array}{l}\text { Turf } \\
\text { Non-turf }\end{array}$ & $\begin{array}{l}10 \\
12\end{array}$ & $\begin{array}{r}3.5 \pm 2.1 \\
17.8 \pm 3.4\end{array}$ & $<.005$ & $\begin{array}{l}-1.0 \pm 1.2 \\
-1.2 \pm 2.0\end{array}$ & n.s. \\
\hline & $\begin{array}{l}26 \text { Oct- } \\
10 \text { Dec } 1980\end{array}$ & $\begin{array}{l}\text { Turf } \\
\text { Non-turf }\end{array}$ & $\begin{array}{l}10 \\
13\end{array}$ & $\begin{array}{l}3.5 \pm 3.0 \\
5.8 \pm 2.1\end{array}$ & n.s. & $\begin{aligned}+9.5 & \pm 10.1 \\
-17.3 & \pm 7.2\end{aligned}$ & $<.05$ \\
\hline & $\begin{array}{l}10 \text { Dec } 1980- \\
31 \text { Jan } 1981\end{array}$ & $\begin{array}{l}\text { Turf } \\
\text { Non-turf }\end{array}$ & $\begin{array}{l}9 \\
6\end{array}$ & $\begin{array}{l}2.2 \pm 1.5 \\
5.0 \pm 3.4\end{array}$ & n.s. & $\begin{array}{c}+1.7 \pm 8.4 \\
-25.8 \pm 16.8\end{array}$ & $<.05$ \\
\hline Gelidium coulteri & $4-26$ Oct 1980 & $\begin{array}{l}\text { Turf } \\
\text { Non-turf }\end{array}$ & $\begin{array}{l}8 \\
5\end{array}$ & 0.0 & $\cdot$ & $\begin{array}{c}+56.9 \pm 25.6 \\
-100\end{array}$ & $<.001$ \\
\hline
\end{tabular}

problematic and suggests that these do not really serve as controls in which urchin use remains unchanged.

Further support for the importance of desiccation in generating the turf morphology was apparent in the response of plants that were transplanted to emergent substratum (Table 6). At the end of the period 4 to 26 Oct, both species showed less bleaching as turfs than as non-turfs with the differences for Corallina vancouveriensis being highly significant $(\mathrm{P}<.005)$. No differences in bleaching were indicated at the end of the next 2 periods (Table 6). Since dead tissues are quickly sloughed or broken off, the consequences of preceding low tide stresses may not have been apparent on the days of these assessments. However, stress effects were manifested in percent cover changes. Turf and non-turf $C$. vancouveriensis exhibited significant differences in percent cover changes during the periods that ended on $10 \mathrm{Dec}$ and $31 \mathrm{Jan}(\mathrm{P}<.05)$. At the end of the first period ( 4 to 26 Oct), 2 of the non- turf' clumps of Corallina vancouveriensis had regrown following a die-back and were indistinguishable from turf clumps. At the 31 Jan assessment, 7 additional $C$. vancouveriensis non-turf specimens had developed the turf form. All non-turf Gelidium coulteri transplanted to emergent substratum exhibited $100 \%$ loss, while turfs showed a mean $57 \%$ increase in cover (Table 6). Even the basal portions of the non-turf form of $G$. coulteri were apparently killed by desiccation since these transplants did not regrow as turfs following die-back.

\section{DISCUSSION}

The distribution of turf and non-turf forms in microhabitats subject to differing degrees of desiccation stress (Table 2) is consistent with the hypothesis that the turf, or aggregate, morphology is adaptive only in habitats where environmental stress precludes the per- 
sistence of the less compacted forms (Hay, 1981). Reciprocal transplants of each form between microhabitats tested this hypothesis. When turf and non-turf forms were transplanted to microhabitats that were exposed at low tide, the non-turf form either bleached and died or bleached and consistently decreased in cover while the turf forms showed significant increases in size (Table 6). Non-turf forms of Corallina vancouveriensis died back to basal crusts and then regrew as turfs; the non-turf form of Gelidium coulteri died completely and did not regrow. When the turf form was transplanted into tide pools where desiccation did not occur, it altered its morphology and soon became indistinguishable from the non-turf form (Table 5). Thus, the non-turf growth form that allows high productivity (Table 3 ) is inconsistent with the ability to persist in physically stressful habitats. The increased compaction of algal biomass that occurs in the turf growth form (Table 1) decreases maximum photosynthetic rate (Table 3; Pfeifer and McDiffett, 1975; Hay, 1981) but allows these species to grow in stressful habitats that would be physically unavailable to them if they were not able to adopt the aggregated form. It is important to note that many of our transplants were moved only a few centimeters from where they were originally attached. Morphological changes appeared to result entirely because of differences in the desiccation/heat regime; changes in wave action or other factors should have been minimal or nonexistent.

On tropical reefs, the turf morphology is often abundant in shallow subtidal areas where desiccation does not occur. Selection for the turf morphology in these habitats appears to occur because the aggregated arrangement of the thalli offers significant protection from reef herbivores (Hay, 1981). It appears that both desiccation and herbivory remove apical cells and result in increased branching and turf formation as these damaged branches regenerate (Isaac, 1956; Dixon, 1958, 1960). On San Nicolas Island, the turf morphology was not retained in tide pools despite an increased abundance of herbivores (Tables 2 and 5). This suggests that grazing on San Nicolas Island may be less intense than on tropical reefs, or that grazers on San Nicolas are not as deterred by the aggregate morphology as are tropical grazers.

Our productivity measurements suggest that increasing the compaction of thalli to form turfs necessarily results in decreased productivity due to increased self-shading and increased barriers to diffusion (Table 3). Other studies have produced similar results (Pfeifer and McDiffett, 1975; Hay, 1981) and have shown that turfs may become so dense that less than $0.2 \%$ of the ambient light reaches lower portions of the thalli. Light in these lower sections may be below compensation.
In non-desiccating habitats where attachment space is limiting, species that could grow only as turfs would be at a competitive disadvantage since turfs are less productive and show a significant reduction in efficiency of substratum utilization when compared with non-turfs (mass or thallus area per unit of attachment area; Table 1). Following this reasoning, previous studies (Hay, 1981) have suggested that turf forms should be abundant only in areas where less compacted, and presumably competitively superior, forms are excluded by environmental stresses. This is the case on San Nicolas Island where turfs occur only on emergent substratum (Table 2) and change into the non-turf form when transplanted into areas without desiccation stress (Table 5). Our estimate for the energetic cost of the turf form (Table 3) may be artificially high if the use of an intermittent stirring regime accentuates the importance of diffusion gradients in limiting photosynthesis in turfs. However, light would still be limiting within the turf matrix and our manipulations have shown that when the turf form is not mandated by stressful physical conditions, turfs rapidly shift to the non-turf morphology (Table 5). This suggests that the turf formation entails a significant energetic cost and that the morphological plasticity of these plants allows them to abandon this expensive form in the absence of off-setting benefits.

Other studies have shown that some turf bases have reduced rates of respiration and have suggested that this spatial partitioning of respiration rate allows turfs to minimize the costs of compacting thalli into the turf matrix (Hay, 1981). In our study, spatial differentiation of photosynthetic activity occurred within the thalli of both the turf and non-turf forms (Table 4). Photosynthesis in the bottom sections of the turfs was 37 to $85 \%$ lower than in the upper sections. However, similar differences in photosynthesis also occurred along the thalli of the non-turf forms. Previous studies (Clenndenning, 1964, 1971; King and Schramm, 1976; Brinkhuis, 1977a, b; Küppers and Kremer, 1978; Littler and Arnold, 1980) have shown photosynthetic differentiation along the thallus of more structurally complex seaweeds. We were surprised to find that spatial partitioning of photosynthesis is also common in seaweeds with considerably less morphological complexity. These gradients may be a result of a lower ratio of photosynthetic to structural tissue in the lower portions of even these relatively simple seaweeds (see Littler and Littler, 1980, for a discussion of interspecies differences in this parameter).

Though decreased productivities were found in the lower portions of the turfs, only Corallina vancouveriensis supported our predictions that turfs would also show a reduction of maintenance costs (i.e. respiration) in the lower portions (Table 4). However, the 
differentiation of respirative demand in C. vancouveriensis was not confined to the turf form in this species. Rates of dark respiration in the top and bottom regions of Gelidium coulteri and Rhodoglossum affine turfs were not significantly different (Table 4), and in all 3 species, the turf bottoms showed respiration rates not significantly different from rates in the bottom portions of non-turfs. Several of these patterns are at variance with physiological patterns shown by Hay (1981) for other turf-forming seaweeds, and his assumption that non-turfs would not show this partitioning is in error for these species.

The advantages of heteromorphic life histories in seaweeds have recently been discussed by Slocum (1980), Lubchenco and Cubit (1980) and Dethier (1981). Our study is similar in that the costs and benefits of different morphs are influenced by shifts in the major environmental parameters, and in that morphological plasticity allows some seaweeds to grow in a greater variety of habitats or conditions. However, the heteromorphic phenomenon studied here differs from those in previous investigations in that (1) the forms we studied may be expressed by a single seaweed at different times (or conceivably simultaneously), and (2) the change in form is not tied to the life history through reproduction. This phenotypic plasticity offers an 'always ready' approach that can induce changes of growth form in response to alterations in environmental conditions. Rather than adopting distinct morphological/reproductive phases (Lubchenco and Cubit, 1980; Slocum, 1980; Dethier, 1981) that increase fitness in a variety of habitats or conditions, species with high phenotypic plasticity may adopt a variety of forms to meet environmental conditions without being developmentally commited (cf. Jackson, 1979) to those conditions should they cease to persist.

Acknowledgements. We are grateful to Dan Benesch for his help and joviality throughout the productivity experiments, to Patrice Storm for technical assistance in the lab, and to Tracy Robert for providing technical improvement of the manuscript. J. Ramus and R. Steneck provided useful comments. We also appreciate the cooperation and assistance of the personnel associated with the US Navy facility on San Nicolas Island, in particular, Ron Dow, W. D. Flora and Tom Wieberg.

This investigation was supported in part by funds from the University of California Patent Fund and Sigma Xi to P. R. T.

\section{LITERATURE CITED}

Abbott, I. A., Hollenberg, G. J. (1976). Marine algae of California. Stanford University Press, Stanford

Bonner, G. M. (1975). The error of area estimated from dot grids. Can. J. For. Res. 5: 10-17

Brinkhuis, B. H. (1977a). Seasonal variations in salt-marsh macroalgae photosynthesis. I. Ascophyllum nodosum ecad scorpioides. Mar. Biol. 44: 165-175
Brinkhuis, B. H. (1977b). Seasonal variations in salt-marsh macroalgae photosynthesis. II. Fucus vesiculosus and Ulva lactuca. Mar. Biol. 44: 177-186

Clendenning, K. A. (1964). Photosynthesis and growth in Macrocystis pyrifera. In: Davy de Virville, A., Jeldmann, J. (ed.) Proceedings 4th International Seaweed Symposium. MacMillan, New York, p. 55-64

Clendenning, K. A. (1971). Photosynthesis and general development in Macrocystis. In: North, W. J. (ed.) The biology of giant kelp beds (Macrocystis) in California. Nova Hedwigia 32: 169-190

Dethier, M. N. (1981). Heteromorphic algal life histories: the seasonal pattern and response to herbivory of the brown crust, Ralfsia californica. Oecologia (Berl.) 49: 333-339

Dixon, P. S. (1958). The structure and development of the thallus in the British species of Gelidium and Pterocladia. Ann. Bot. 22 (87): 353-368

Dixon, P. S. (1960). Studies on marine algae of the British Isles: Ceramium shuttleworthianum (Kutz) Silva. J. mar. biol. Ass. U. K. 39: 375-390

Gerard, V. A., Mann, K. H. (1979). Growth and production of Laminaria longicruris populations exposed to different intensities of water movement. J. Phycol. 15: 33-46

Hay, M. E. (1981). The functional morphology of turf forming seaweeds: persistence in stressful marine habitats. Ecology 62: 739-750

Isaac, W. E. (1956). The ecology of Gracilaria confervoides (L.) Grev. in South Africa with special reference to its ecology in the Saldanha-Langebaan Lagoon. In: Braarud, T., Sorensen, N. A. (ed.) Second International Seaweed Symposium. Pergamon Press, New York, p. 173-185

Jackson, J. B. C. (1979). Morphological strategies of sessile animals. In: Larwood, G., Rosen, B. (ed.) Biology and systematics of colonial organisms. Academic Press, London, p. 499-555

King, R. J., Schramm, W. (1976). Determination of photosynthetic rates for the marine algae Fucus vesiculosus and Laminaria digitata. Mar. Biol. 37: 209-213

Küppers, U., Kremer, B. P. (1978). Longitudinal profiles of carbon dioxied fixation capacities in marine macroalgae. Plant Physiol. 62: 49-53

Littler, M. M., Arnold, K. E. (1980). Sources of variability in macroalgal primary productivity: sampling and interpretive problems. Aquat. Bot. 8: 141-156

Littler, M. M., Littler, D. S. (1980). The evolution of thallus form and survival strategies in benthic macroalgae: field and laboratory tests of a functional form model. Am. Nat. 116: $25-44$

Lubchenco, J., Cubit, J. (1980). Heteromorphic life histories of certain marine algae as adaptations to variations in herbivory. Ecology 61: 676-687

Pfeifer, R. F., McDiffett, W. F. (1975). Some factors affecting the primary productivity of stream riffle communities. Arch. Hydrobiol. 75: 306-317

Slocum, C. J. (1980). Differential susceptibility to grazers in two phases of an intertical alga: advantages of heteromorphic generations. J. exp. mar. biol. Ecol. 46: 99-110

Steneck, R. S., Adey, W. H. (1976). The role of environment in control of morphology in Lithophyllum congestum, a Caribbean algal ridge builder. Botanica mar. 19: 197-215

Taylor, P. R., Littler, M. M. (1982). The roles of compensatory mortality, physical disturbance and substrate retention in community development and organization of a sand-influenced rocky intertidal community. Ecology 63: 135-146 